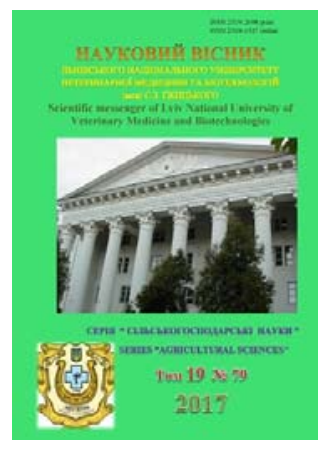

Науковий вісник Львівського національного університету ветеринарної медицини та біотехнологій імені С.З. Гжицького

Scientific Messenger of Lviv National University of Veterinary Medicine and Biotechnologies

doi:10.15421/nvlvet7902

ISSN 2519-2698 print

ISSN 2518-1327 online

$\underline{\text { http://nvlvet.com.ua/ }}$

\title{
Conceptual framework for the assessment of the nutritional and biological value of the plant Galega orientalis (LAM)
}

\author{
L.M. Darmohray ${ }^{1}$, G.M. Sedilo ${ }^{2}$ B.V. Gutyj ${ }^{1}$ \\ myrolub15@gmail.com \\ ${ }^{1}$ Stepan Gzhytskyi National University of Veterinary Medicine and Biotechnologies Lviv, \\ Pekarska Str., 50, Lviv, 79010, Ukraine; \\ ${ }^{2}$ Institute of Agriculture in the Carpathian region NAAS, \\ Grushevskogo Str., 5, Obroshino, 81115, Ukraine
}

\begin{abstract}
Conducted a comprehensive comparative study of the nutritional and biological value Galega orientalis (Lam): the solubility of the protein in vitro - Galega's seeds, leaves, hay, which was harvested in the phase of budding - beginning of flowering. It is believed to be the essential influence of feed type on the solubility of the protein. According to the conducted studies it has revealed that the solubility of the feed protein is in the range from $37.0 \%$ to $50.0 \%$. The rate of solubility of Galega orientalis (Lam) seed protein is $50.0 \%$, litestock $-40.0 \%$, and hay $-37.0 \%$ from its total. The research results indicate that the protein of Galega orientalis (Lam) refers to the feed with the average level of solubility. It has researched qualitative assessment of the biologically active substances content in organs of Galega orientalis' (Lam) plants. It has identified the highest content of flavonoids and saponins in rosette leaves and ascorbic acid in the organs of plants and petals. There is the high content of tannins found in the petals of Galega orientalis (Lam). There is a high content of coumarins and water-soluble polysaccharides in the roots of the studied plants. Phytochemical studies of the plant Galega orientalis (Lam) indicates the absence in it of cardiac glycosides and antrahlikozydiv. It was first conducted testing on antimicrobial activity of a plant Galega orientalis (Lam) on the growth pure cultural of bacteria gram positive (Micrococcus luteus), gram negative (Escherichia coli XL1, DH5) and yeasts (Saccharomyces cerevisiae W303). The material for the study was dried vegetative mass Galega orientalis (Lam) in the phase of budding and early flowering. As a result of the experiment was revealed that $20 \%$ concentration of aqueous extract of this plant had inhibitory effects on the growth of pure cultures of bacteria and yeast. It has grounded reasonably possible relationship between the antimicrobial activity of the extract of this plant and the lack of bloating in cows. It has outlined prospects of further researches of this problem.
\end{abstract}

Key words: Galega orientalis (lam), organs of plants, fodders, splitting in the rumen, protein solubility, biologically active substances, antimicrobial activity.

\section{Citation:}

Darmohray, L.M., Sedilo, G.M., Gutyj, B.V. (2017). Conceptual framework for the assessment of the nutritional and biological value of the plant Galega orientalis (LAM). Scientific Messenger LNUVMB, 19(79), 9-12.

\section{Introduction}

A comprehensive approach to the definition of nutritive and biological value of plants and forage provides an opportunity to reveal their influence on the functioning of the organism and productivity of animals (Yanovuch and Solohub, 2000; Darmohray, 2009; Darmohray, 2010; Darmohrai, 2016). After all, feeding is the axis around which revolves everything that gives the possibility of implementation of modern genetic potential of the animals.

An important factor that must be considered in formulating rations for animals is the establishment of the content in feed and availability of biologically active substances in the process of exchanging. For ruminants it is also necessary to know the degree of splitting of fodder protein in the rumen (Cyupko, 1999). One of the indica- tors that is used to predict the extent of splitting of fodder protein in the rumen is its solubility (Zamaziy, 2004). Solubility and razmalyvanie crude protein of forages in most cases closely correlated.

Today in the scientific world continues to search for new and more stable strong components of antimicrobial action of natural origin in contrast to the existing synthetic antibiotics and improvement of microbiological purity of food products, feed additives. According to the publication of domestic and foreign authors there is a considerable interest to study the antimicrobial activity of nontraditional but promising agricultural crops, one of which is Galega orientalis (Lam), which belongs to perennial legumes (Hrinkevich, 1983; Borovsk..., 1987; Cyupko, 1999; Zamaziy, 2004; Darmohray, 2009; Darmohray and Vlizlo, 2015; Darmohray and Gonchar, 2015). Using of 
natural substances that have antimicrobial action, is quite important given several things: the micro-organisms have no resistance to them and perhaps long-term use; do not cause harmful (adverse) impact on human and animal; thanks to its braking effect on the unwanted microflora can be applied in the food industry, because food processing not allowed to use synthetic antibiotics (with the exception of the peptide antibiotic Nisin).

Therefore, the study of questions of versatile nutritional and biological value of feed remains relevant.

The aim of our work was to determine and compare the solubility of protein of seeds, leaves and hay from Galega orientalis ( $L a)$, to determine the content of biologically active substances (BAS) in the organs of plants Galega orientalis ( $\mathrm{La}$ ) and to test the antimicrobial properties of aqueous extract of this plant in vitro.

\section{Material and methods}

The material for the study of solubility of protein were: seeds, leaves and hay from Galega orientalis (La). The solubility of protein was determined in vitro in a buffer solution $(\mathrm{NH} 4)_{2} \mathrm{SO}_{4}(\mathrm{pH}=6.5)$ (Borovsk..., 1987). Calculating the solubility of crude protein was considered the amount of crude protein, which is passed into the solution and the amount of crude protein in feed to incubation. Nitrogen content was determined by Keldal.

Phytochemical examination (qualitative evaluation) of the content BAR in the bodies of plants Galega orientalis (La) was carried out according to the method of M.I. Hrinkevich (Hrinkevich, 1983). The material for the study of testing antimicrobial properties of aqueous extract of this plant served as the dried vegetative mass of plants in phases of budding and beginning of flowering. In the experiments used the Endo agar for the growth of gram-negative bacteria and LB medium for the growth of both gram-positive and gram-negative bacteria, and wortagar for yeast. The research was conducted at the Institute of cell biology NAS of Ukraine, Department of analytical biotechnology (Sen and Batra, 2012).

It was prepared $10 \%$ and $20 \%$ extract of the preparation (dried herb) by boiling and maceration for 10 15 hours. The extracts were sterilized by cold filtration. After that, on the surface of the cups with agaritine environment was applied in $0.1 \mathrm{ml}$ of the investigated extract and sowed her grass proper culture. All the experiments were performed in 10 control and 10 experimental cups. We analyzed the appearance of the colonies for 2-3 days after seeding at $+30^{\circ} \mathrm{C}$ (yeast) and the first day at +35 to $37^{\circ} \mathrm{C}$ (bacteria), comparing experimental variants with the control (without extract).

Obtained in experiments digital data processed biometrico using computer programs in MS Office 2003 program «Statistica». The results of mean values was considered statistically significant $*-\mathrm{P}<0.05$, ** $\mathrm{P}<0.01, * * *-\mathrm{P}<0.001$

\section{Results and discussion}

The results of researches on determination of solubility of protein feed of different origin are shown in figure 1. According to the conducted laboratory studies were determined a significant influence of the type of food and organs of plants on the degree of solubility of the protein.

Data are given on the figure indicate the dependence of the index of solubility of protein from the morphological structure and origin of feed. The solubility of protein of study forages ranges from $37,0 \%$ to $50,0 \%$. The difference is caused by the structure and chemical composition of forages.

The index of protein solubility for hay from Galega orientalis (Lam.) is higher than gluten five times. The protein of leaflets of Galega orientalis (Lam.) dissolved in buffer solution rather than protein hay. This is probably due to the hardening the stem and formation the slightly soluble fiber complexes and nitrogen compounds. The protein seed Galega orientalis (Lam.) dissolved in 50,0\% of its total. It is a lower solubility compared to the solubility of protein of soy, despite the fact that these foods have the same high protein content. This may be the amino acid composition of protein, namely the content of branched amino acids, which affect the number of the indices.

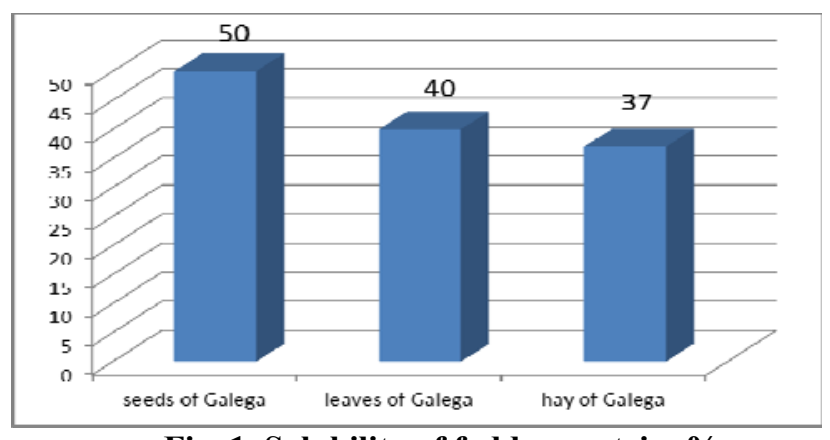

Fig. 1. Solubility of fodder protein, \%

Fodder and medicinal properties of plants depend on the presence of different chemical structure and productive action of substances. The most important of these substances are alkaloids, glycosides, saponins, tanning agents, flavonoids, essential oils, plant hormones, vitamins, trace elements, organic acids, mineral salts, resins and other.

For a more complete characterization of alternative and rare crop Galega orientalis (Lam.) we have conducted research for determination of some biologically active substances in the bodies of plants. Qualitative assessment of the content of the BAS in the bodies of plants Galega orientalis (Lam.) is presented in table 1.

This plant is a typical bean plant. Alkaloids are available only in the rosette leaves $(++)$ a sufficient content. Qualitative assessment shows that this plant is a high content of coumarins, especially in the roots. In this culture is the high content of flavonoids, especially in the rosette leaves, tanning agent petals and water-soluble polysaccharides is in the roots. It should be noted that in Galega orientalis (Lam) no shows qualitative assessment, heart glycosides and anthraglycosids. Separately it is necessary to emphasize about the high content of ascorbic acid in the leaves and petals except roots. 
Content of biologically active substances in the bodies of plants Galega orientalis (Lam.)

\begin{tabular}{|c|c|c|c|c|}
\hline \multirow{2}{*}{ BAS } & \multicolumn{4}{|c|}{ Organs of plant } \\
\hline & rosette leaves & roots & stem leaves & petals \\
\hline Alkaloids & ++ & $\mathrm{H}$ & - & - \\
\hline Coumarins & ++ & +++ & ++ & ++ \\
\hline Flavonoids & +++ & ++ & ++ & ++ \\
\hline Heart glycosides & - & - & - & - \\
\hline Saponins & +++ & ++ & ++ & ++ \\
\hline Tannins & ++ & ++ & ++ & +++ \\
\hline Anthraglycosides & - & - & - & - \\
\hline Water-soluble polysaccharides & ++ & +++ & ++ & ++ \\
\hline Ascorbic acid & +++ & + & ++ & +++ \\
\hline
\end{tabular}

Legend: ++ + - the high content of the BAS; ++ - the sufficient level; + - low (traces); $N$ - the content is not determined.

In the previous stages of our research it was established and noted in publications that grazing cows on pasture with Galega orientalis (Lam) in the dew or in the rain at one of the cows did not this was caused considering the fact that this culture belongs to the legumes. With the aim of finding the possible mechanisms of this phenomenon, we performed model microbiological studies. Because research on the symbiotic microflora of the rumen is a complex problem, we studied the effect of different concentrations of aqueous extracts of Galega orientalis (Lam) on growth of pure cultures of bacteria and yeast.

Test results of antimicrobial activity of the test drug is given in the table 2 .

Table 2

Antimicrobial Activity of Water Extract of the Plant Galega orientals (Lam) against Bacteria and Yeast,

$(\mathbf{M} \pm \mathbf{m}, \mathbf{n}=\mathbf{1 0})$

\begin{tabular}{|c|c|c|c|c|}
\hline Group & \multicolumn{2}{|c|}{ Gram-negative } & $\begin{array}{c}\text { Gram - } \\
\text { positive }\end{array}$ & Yeasts \\
\cline { 2 - 5 } & $\begin{array}{c}\text { E.coli } \\
\text { XL1) }\end{array}$ & $\begin{array}{c}\text { E.coli } \\
\text { (DH 5) }\end{array}$ & M. Luteus & $\begin{array}{c}\text { S.cerevisiae } \\
\text { (W 303) }\end{array}$ \\
\hline Control & $540 \pm 15$ & $389 \pm 4$ & $1921 \pm 81$ & $59 \pm 5$ \\
\hline Experiment & $430 \pm 9$ & $272 \pm 6$ & $1694 \pm 8$ & $41 \pm 4$ \\
& $* * *$ & $* * *$ & $*$ & $* *$ \\
\hline
\end{tabular}

It was noticed that examining culture products in concentration $10 \%$ didn't influence the growth of bacteria Gram positive, Gram negative, yeasts much. Due to increasing in concentration of water extract up to $20 \%$ found that Petri-dish control group was grown at $540 \pm 15$ colonies of E. coli strain XL1 and experienced with the addition of $20 \%$ of the preparation Galega orientalis (Lam) there were 110 colonies less. Therefore, it was observed inhibition of growth of bacteria by $20.0 \%$ $(\mathrm{P}<0.001)$ compared to the control cups. Intergroup difference in this indicator is statistically probable. The test results of the antimicrobial activity of the test preparation are shown in table 1 .

In the study of antimicrobial action of $20.0 \%$ water extract of Galega orientalis (Lam) on the growth of gramnegative bacteria E. coli strain DH 5 it was found that in the experimental cups were 117 smaller colonies than the control. In percentage terms this means inhibition of bacterial growth by $30.0 \%(\mathrm{P}<0.001)$.

It was conducted microbiological studies indicate that was slightly less antibacterial activity of an investigational preparation against gram-positive bacteria M. luteus. It was found that $20 \%$ of water extract of Galega orientalis (Lam) inhibits the growth of microorganisms by $12.0 \%$ $(\mathrm{P}<0.05)$ compared with control. It has showed the negative effect of water extract of Galega orientalis (Lam) on the growth eukariotic microorganisms-yeast saccharomyces cerevisiae strain W303. It was found that in the experimental cups the number of colonies was $30.5 \%$ $(\mathrm{P}<0.01)$ compared with the control.

Along the way, to note that in all cases, experimental studies of the addition of the drug Galega orientalis (Lam) was not altered colony morphology strains tested.

\section{Conclusions}

Based on the results of gluten refers to feed with low solubility, protein Galega orientalis (Lam) is middle, soybean and sunflower meal are with a high degree of solubility of the protein. In this regard, the feeding of ruminant animals studied fodder needs adequate amounts of protein will differently affect the efficiency of the use of nitrogenous compounds.

The analysis argues that the protein seeds, leaves and hay from Galega orientalis (Lam.) have an average degree of solubility. It has studied the essential influence of type of feed on the degree of protein solubility. The highest solubility has found in seeds $-50,0 \%$, the letter $40,0 \%$, and lowest in the manger $-37,0 \%$.

According to the conducted phytochemical research found that in the bodies of plants (Galega orientalis (Lam) is a sufficient level of alkaloids and coumarins in the rosette leaves $(++)$, as well as the relatively high content of flavonoids in the rosette leaves and ascorbic acid in the petals and leaves the investigated plants. On the content of the BAS, this plant is characteristic bean plant. It is expedient to conduct more extensive research using modern methods and techniques to better understand and address this issue.

Obtained results allow to note a slight antimicrobial effect of a $20 \%$ water extract of Galega orientalis (Lam) on growth of pure cultures of gram-negative and grampositive bacteria and yeast. This fact can be used in the food industry as an antimicrobial agent of natural origin to preserve and ensure the microbiological purity of the products, and also suggests that the lack of this was caused from animals who were fed this plant, may be associated with the inhibition of microorganisms. 
Prospects for further research. It is advisable to carry out extensive research using modern methods and techniques for deeper understanding and solution of this issue and also to expand the range of test-cultures and the range of concentrations of the studied drug with respect to determine the problem.

\section{References}

Darmohray, L.M. (2009). Metodychni recomendaciyi shchodo vykorystannya kormiv iz (Galega orientalis (Lam) riznymy vydamy tvaryn [Methodical recommendations of using fodder of (Galega orientalis (Lam) for different kinds of animals]. Lviv (in Ukrainian).

Yanovuch, V.H., Solohub, L.I. (2000). Biolohichni osnovy transformaciyi poshyvnyh rechovyn u shuyinyh tvaryn [Biological foundations of transformation of nutrients from ruminants]. Lviv (in Ukrainian).

Cyupko, V.V. (1999). Biolohichni osnovy bilkovoho shuvlennya i normuvannya bilka dlya shuiynyh [Biological bases of protein supply and regulation of protein to ruminants]. Zbirnyk naukovyh prac [Collection of scientific works]. (Inst. tv-va) Kharkiv, 71-75 (in Ukrainian).

Zamaziy, M.D. (2004). Rozshchepliyvanist proteyinu kormiv - vajlyvyiy factor $\mathrm{v}$ zabezpechenni molochnoyi productyvnosti koriv [Splitting of protein feed is an important factor in ensuring the productivity of dairy cows]. Visnyk Sumskoho nacionalnoho ahrarnoho universytetu [Bulletin of Sumy national agrarian University]. Sumy. 7(12), 46-49 (in Ukrainian).

Borovsk (1987). Izuchenie pishchevareniya u shvachnyh (metodicheskie ukazaniya) [Study of digestion in ruminants (methodical recommendations)] (in Russian).

Hrinkevich, N.I. (1983). Himicheskiy analiz lekarstvennyh rasteniy [Chemical analysis of medicinal plants]. M.: Vysshaya shkola (in Russian).

Darmohray, L.M. (2009). Fitohimichne vyvchennya vmistu biolohichno aktyvnyh rechovyn ta testuvannya antymicrobnoi actyvnosti halehy shidnoi (Galega orientalis (Lam). Nauk. Visnyk Lvivskoho nacionalnoho universytetu veterynarnoi medycyny ta biotechnolohiy im. S.Z. Hshyzkoho. Lviv. 11, 3(42), 239-242 (in Ukrainian).

Estrada, A. (2000). Isolasion and evaluation of Immunologigal adjuvant activities of saponins from Polygaja senega L. Comparative Immunology. Microbiol. Infect. Dis. 23, 27-43.

Irobi, O.N. (1994). Antimicrobial actuvity of the barc of Bridelia ferruginea. Int. J. Pharmacog. 34, 87-90.

Olorundare, E.E. (1992). Antibacterial properties of leaf extract of Cassia alata. Biol. Res. Com. 4, 113-117.

Sibanda, T. (2008). In vitro antibacterial regimes of crude aqueous and acetone extracts of Garcinia kola seeds. J. Biol. Sci. 8(1), 149-154.

Darmohray, L.M., Vlizlo, V.V. (2015). Doslidzennya antymicrobnyh vlastyvostey vodnoho ekstractu roslyny Galega orientalis (Lam). Naukovyy visnyk NUBiT. Kyiv. 214, 51-58 (in Ukrainian).

Darmohray, L.M., Gonchar, M.V. (2015). Bioactivity of Pure Cultures of Bacteria and Yeast in the Background Action of the Water Extract of a Plant Galega orientalis (Lam). Research \& Reviews: Journal of Veterinary Sciences. 1(1), 82-85.

Darmohray, L.M. (2010). Experimental justification for the use of nutrients and biologically active substances from food (Galega orientalis ( $L a$ ) different kinds of animals. - Manuscript. Doctor of Agricultural Sciences, specialty 06.02.02 - animal nutrition and feed technology. - Lviv National University of Veterinary Medicine and Biotechnologies named after S.Z. Gzhytskyj, Lviv, 42 Lviv (in Ukrainian).

Darmohrai, L.M. (2016). Analizy i metody otsinky pozhyvnosti kormiv. Navchalnyi posibnyk. Lviv (in Ukrainian).

Sen, A., Batra, A. (2012). Evaluation of antimicrobial activity of different solvent extracts of medicinal plant: Melia azedarach L. Int. J. Gurr. Pharm. Res. 4(2), 67-73.

Received 4.09.2017

Received in revised form 26.09.2017

Accepted 29.09.2017 